Article received on $22^{\text {nd }}$ January 2015

Article accepted on $12^{\text {th }}$ May 2015

UDC: 783 (496.5)

$091=18: 78$

\title{
Meri Kumbe
}

Universiteti i Arteve, Tiranë, Albania

Fakulteti i Muzikës,

Departamenti Muzikologjisë,

\section{MUSIC IN ALBANIA THROUGH THE MEDIUM OF PAPER MUSICAL MANUSCRIPTS}

\begin{abstract}
The aim of this paper is to present the musical Byzantine manuscripts, kept in the Central State Archive of Albania. It particularly focuses on the historical importance they had in the evolution of religious music in Albania and Albanian music per se, whilst providing important information related to the specificity of names and other music elements. This paper also focuses on the characteristics of these "papers", and "papers" in general, published through the medium of paper, from papers (article, essay, study) as a "text".
\end{abstract}

Keywords: Musical manuscripts, Albania, Byzantine music, musical notation, ectophonetic notation.

Albania is a small country, geographically located in the northwestern part of the Balkan Peninsula. Its music tradition through the centuries has developed within the two groups of the population, namely the Gheg and the Tosk, which are respectively situated in North and South Albania. This cultural division is not only reflected in the folkloristic diversity but has also influenced both the sacral (religious) and profane music traditions of the country. In this paper, entitled "Music in Albania through the medium of paper, musical manuscripts" the aim is to address key questions, such as: What are the first sources of written music in Albania? How Albanian "papers", and papers in general, have reflected the music tradition of the country?

The very first traces (evidence) of musical notation in Albania were found in medieval musical manuscripts that were written in Byzantine notation. Today, these manuscripts are kept in the State Central Archive (Tiranë, Albania), and 
Kumbe, M.: Music In Albania through the Medium of Paper Musical Manuscripts

constitute part of a collection called: "The Codex of Albania”, which consists of 102 manuscripts and 17 fragments. ${ }^{1}$ Most of the codex has a liturgical content, which originated from the city of Berat. In this collection, of musicological interest are nine manuscripts with a biblical content, in which fragments of them exist in ectophonetic notation, and six are manuscripts with Byzantine notation.

The manuscripts with ectophonetic notation (Examples 1-2) are:

1. Lectionary Berat 3 (shek. IX, parchment)

2. Lectionary Vlorë 7 (shek. XII, parchment)

3. Lectionary Berat 8 (shek. XII, parchment)

4. Lectionary Berat 9 (shek. XII, parchment)

5. Tetraevangelion Berat 15 (shek. X, parchment)

6. Lectionary Berat 16 (shek. XIII, parchment)

7. Lectionary Berat 21 (1181, parchment)

8. Tetraevangelion Berat 26 (1312, parchment)

9. Lectionary Berat 89 (shek. XIV, parchment)'

\section{Examples 1-2}

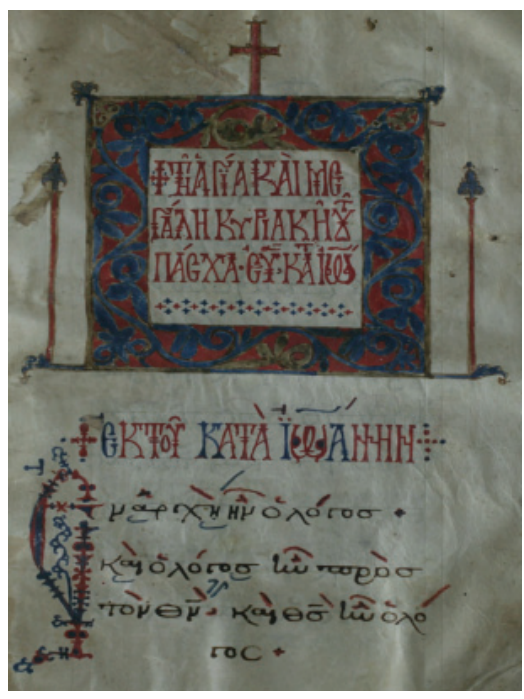

16, f. $1 r .\left(13^{\text {th }}\right.$ century $)$

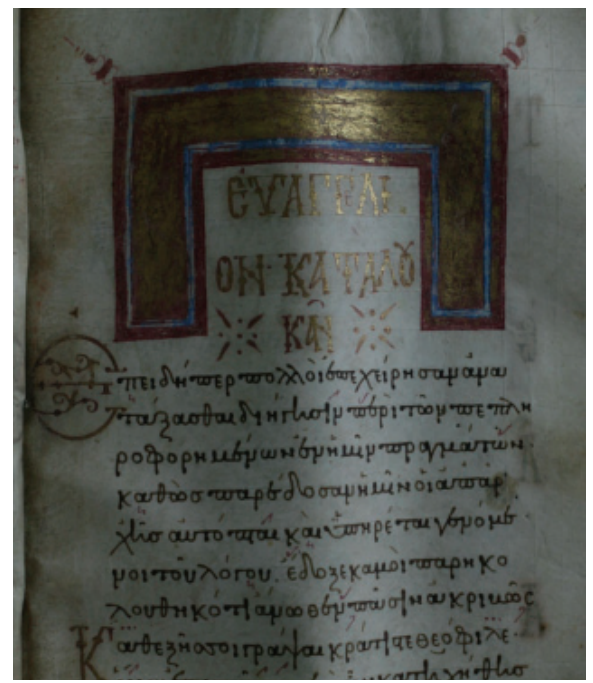

2) Berat 15 , f. $175 \mathrm{r},\left(10^{\text {th }}\right.$ century $)$

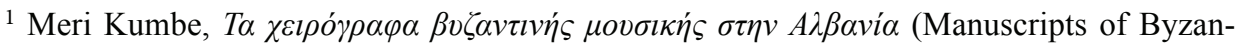
tine Music in Albania), (Master thesis), School of Ecclesiastical and Social Theology, Aristotle University of Thessaloniki, Greece, February 2012, p. 22. (http://invenio.lib.auth.gr/ record/128954)
} 
We also encounter ectophonetic notation in the folios $45-46$ of the codex Berat 1, known as the codex "Beratinus Purpureus" ( $6^{\text {th }}$ century). One should note that the ectophonetic notation in this manuscript was of a later date (Examples 3-4).

\section{Examples 3-4}

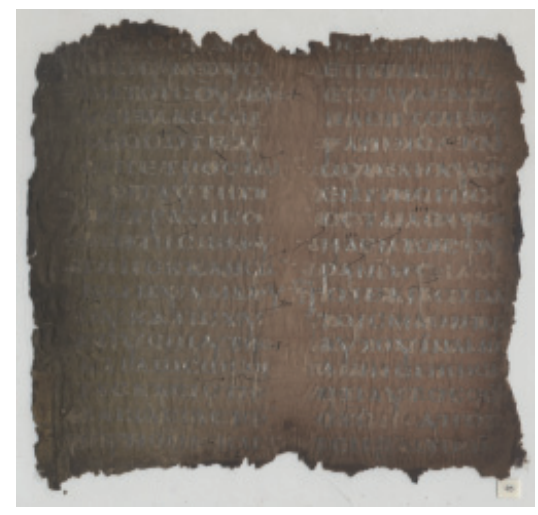

3) Berat 1, f. 45 (original)

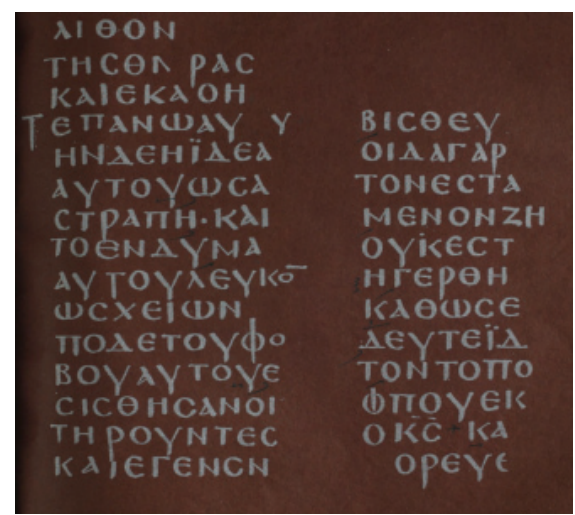

4) Berat 1, f. 45 (facsimile)

The six manuscripts with Byzantine notation are'2:

1. Berat 23 - Hirmologium, 1292, paper, Middle Byzantine Notation (Round Notation)

2. Përmet 81 - Stichiarium of Menologio, Triodio, Pentikostario dhe Parakletikis (Oktoikut), 14 ${ }^{\text {th }}$ century, parchment, Middle Byzantine Notation (Round Notation)

3. Korçë 72 - Anthologji, 1736, paper, Middle Byzantine Notation (Round Notation)

4. Elbasan 87 - Anthologi - Hirmologium, 1808, paper, Exegetical notation

5. Berat 90 - Anastasimatario of Petro Peloponisit, $18^{\text {th }}-19^{\text {th }}$ centuries, paper, Exegetical notation

6. Tiranë 95 - Mixed codex, $19^{\text {th }}$ century, paper, New Method

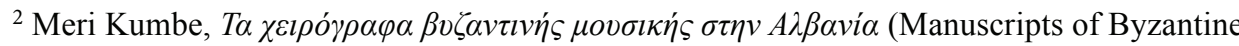
Music in Albania), (Master thesis), School of Ecclesiastical and Social Theology, Aristotle University of Thessaloniki, Greece, February 2012, p. 38. (http://invenio.lib.auth.gr/ record/128954)
} 
To define the typology of the musical manuscripts and to sort them out chronologically, we relied primarily on data such as the titles, notes, date, etc., given in the manuscripts in the cases where they existed, and secondly, on the musical content of the manuscripts, as well as on the music notation used, on the names of the composers to whom they were ascribed, and on the codicological characteristics.

With regard to the above data, two important characteristics were observed: 1) the different provenance (Example 5), and 2) the variability in terms of both chronology and typology (Example 6). The musical manuscripts of Albania came from five different cities and regions in the country, such as: Tiranë, Elbasan, Korçë, Berat and Përmet, that is, from the central, southern and eastern parts of Albania.

\section{Examples 5-6}

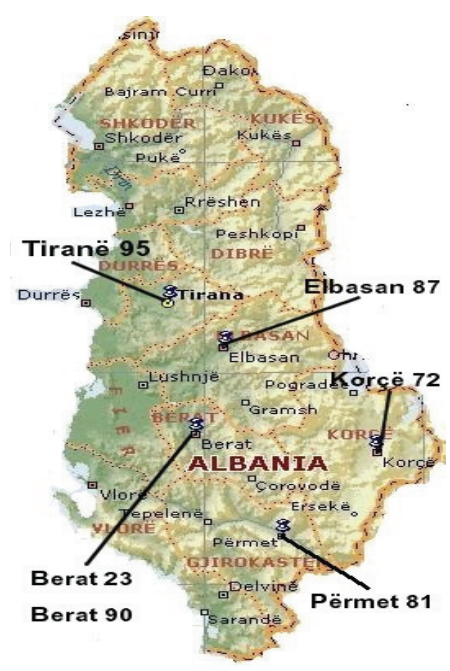

5) the provenance of the musical manuscripts

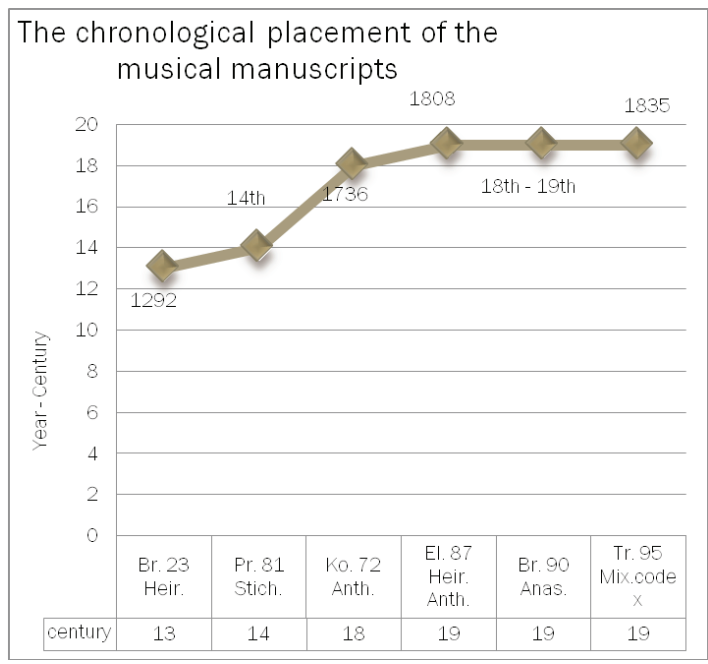

6) The chronological placement of the musical manuscripts

From a chronological perspective, they date from the thirteenth century to the nineteenth century. Despite their limited number, the musical manuscripts' provenance and their typological and chronological variety testify to the existence, continuity (from the thirteenth to the nineteenth century), and level of dissemination of Byzantine psaltic art in Albania.

The manuscript Berat 23 is the oldest preserved musical manuscript in the collection "Kodikët e Shqipërisë" (The Codex of Albania) at the Central State Ar- 
chive, as well as being the oldest manuscript written on Arabic paper, called bombycina. This codex is the Hirmologium (as is written in the note of the f. $1 \mathrm{r}$ and at the beginning of the f. 91v.), and its musical notation is classified in the second period of Byzantine notation, in Middle Byzantine notation (Round Notation). In the ff. 55v and 159r (Example 7), there are two cryptographical notes ${ }^{3}$ from which we learned the names of the author (scribe) of the codex and his village:

$$
\begin{aligned}
& +\xi \nu \beta \omega \alpha \beta \psi h \pi \varepsilon \psi \lambda \chi \chi \psi \theta \kappa \varepsilon h \nu \lambda \chi \pi \theta \varkappa \theta v \theta
\end{aligned}
$$

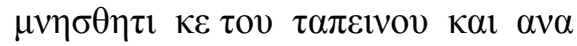

$$
\begin{aligned}
& \mu h \lambda \chi \subseteq \lambda \psi[\ldots \ldots . . .] \chi \xi \xi v \theta \beta o
\end{aligned}
$$

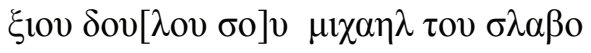

$$
\begin{aligned}
& {[\kappa] \lambda \chi 0 \lambda \chi[\ldots] \pi[. .] \zeta \lambda \theta \tau \theta \theta v \psi \lambda \omega \chi \beta \nu \alpha \varepsilon h} \\
& {[\pi] \mathrm{ov} \lambda \mathrm{ov}[\ldots] \tau[\mathrm{ov}] \gamma \rho \alpha \psi \alpha \nu \tau \mathrm{s}, \tau \eta \nu \theta \varepsilon \iota} \\
& \theta v \eta \varkappa[\ldots] v \psi \theta \chi \chi \psi \beta v[\ldots] \kappa \lambda v \sigma \lambda\left\langle\lambda \lambda \chi \varsigma \varepsilon \pi^{\lambda} \lambda \varepsilon\right. \\
& \alpha \nu \beta \mathrm{r}[\beta \lambda \mathrm{o}] v \tau \alpha \nu \tau \eta \nu[\ldots \alpha] \pi \mathrm{o} \chi \omega \rho \mathrm{ov} \delta \varepsilon \kappa \rho \varepsilon \\
& \theta \omega v h \pi \lambda \chi[\omega \ldots .] v \\
& \alpha \sigma v i \kappa o v[\varsigma \alpha \mu \eta] v \text {. }
\end{aligned}
$$

\section{Example 7}

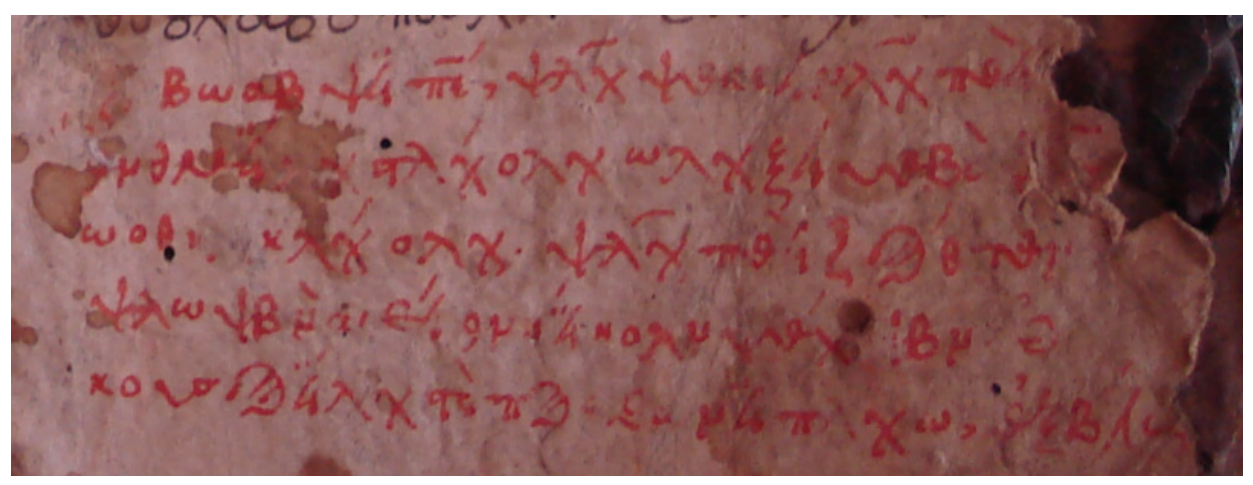

7) Berat 23, f. 159r

\footnotetext{
${ }^{3}$ The cryptographical notes were read by Dr. Agamemnon Tsilikas.
} 
Kumbe, M.: Music In Albania through the Medium of Paper Musical Manuscripts

(I, the humble and unworthy Michail Slavopoulos, wrote this book, from the village Kreasnikos, Amin)

In the f. 159r, we read also the record:

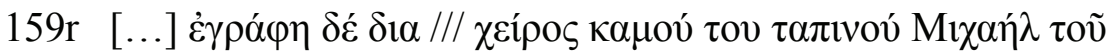

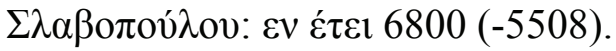

(Was handwritten by me, the humble Mihail Slavopoulos, in the year 6800 $(-5508))$

Undoubtedly, the manuscript Berat 23 is the most important one among the other musical manuscripts of Albania. The specificity of this codex, compared with codices of the same type, is related to the articulation of its contents. In particular, it is organized in three parts, where the first one is the Hirmologium, which is based in the echos order (or as it is known in Byzantine musicology, in KAO). It is followed by the Makarismi, and the third part returns to the Hirmologium organized and initially based on the echos order and continues after with the Minologio. During the detailed analytical study of this manuscript, we compared the text of the eirmi in the codex Berat 23 with the text of the eirmi provided in the edition Eirmologio by Eustratidi. ${ }^{4}$ As it was observed, the texts of many eirmi in the manuscript Berat 23 are either partly different or do not exist at all in EE. ${ }^{5}$ The codex Berat 23 still has its original binding and its original wooden boards.

The other musical manuscripts of Albania are also important for the history of religious music in Albania, even though they do not bear the same unique characteristics as Berat 23.

The manuscript Përmet 81 , is the second oldest musical manuscript of the collection Codex of Albania. It constitutes a parchment manuscript of the fourteenth century. Unfortunately, its binding has been destroyed and today only the lower board is preserved. In this manuscript we did not find any reference about the scribe or its chronology or typology. We defined this codex as Sticherarium of Minologio, Triodio, Pentikostario and Paraklitikh (Oktoecho), based on its musical content. The Përmet 81 is a manuscript of the fourteenth century and the musical notation used in it is classified in the second period, Middle Byzantine Notation (Round notation). During our study we realised that the letter $\zeta$ used in the text of Përmet 81 is an Epirus $\zeta$, and means that this manuscript may have been produced in Epirus (Example 8).

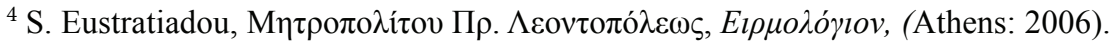

${ }^{5}$ Idem.
} 


\section{Example 8}

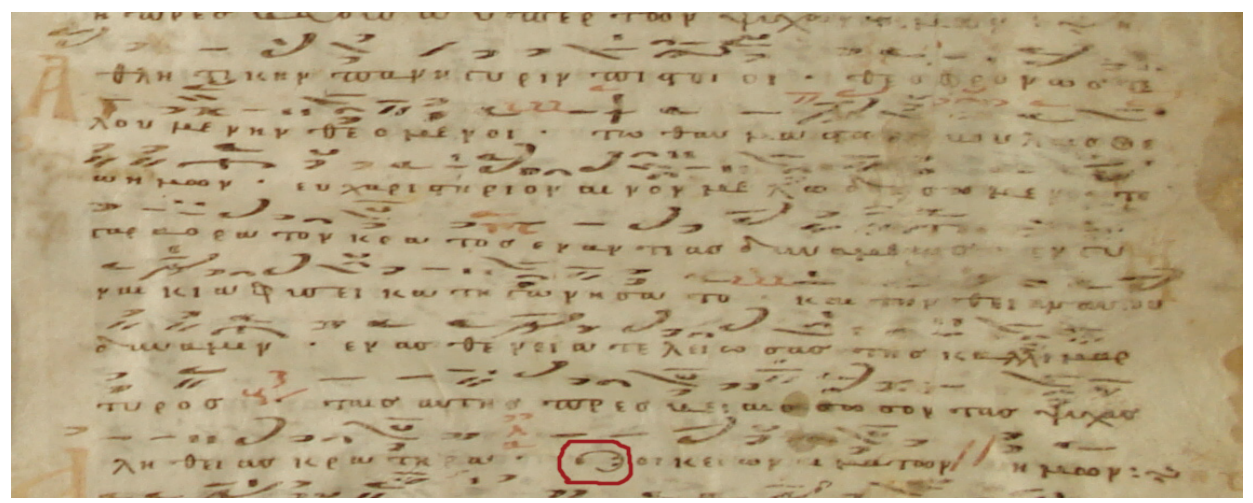

8) Përmet 81, f. 8r

The manuscripts Korçë 72 and Elbasan 87 were written in the $18^{\text {th }}$ and $19^{\text {th }}$ century. The information given is presented as follows:

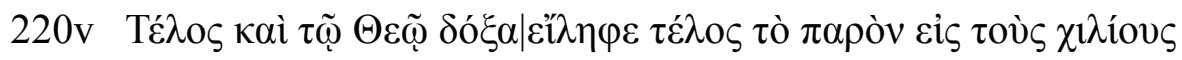

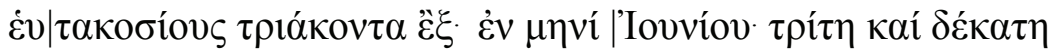

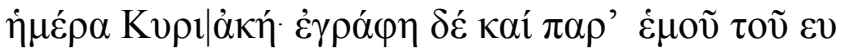

(The end, Glory be to God, this manuscript was finished in 1736, on Sunday, the $10^{\text {th }}$ day of the month of June, written by me Eu)

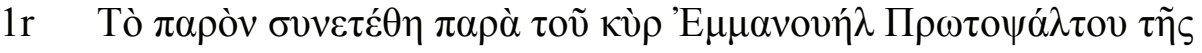

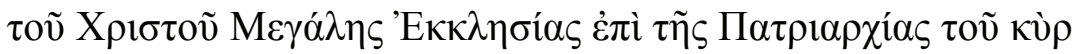

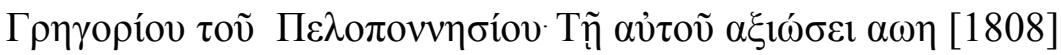

(This was composed from Emannouel Protopsalti of the Big Christ Church, when the Patriarch was Mr. Gregorios Peloponnisios)

The manuscript Korçë 72, is an Anthology of music and was written in 1736. The musical notation is classified in the second period, Middle Byzantine notation. In this manuscript, many composers' names are mentioned, such as: Germanos, Patriarch of the New Patras, Damianos the Melodos, Ioannis Lampantarios of Klada, Ioannis Koukouzeli, Ioannis Glykes, Ioasaf, the new Koukouzelous, etc. This codex was purchased by the state archive on the December 30, 1967, from its holder Mrs. Elisaveta Mole, for 150 lek. $^{6}$

\footnotetext{
${ }^{6}$ Fondi DPA, Dosje nr. 8, Viti 1967, f. 14, Urdhër pagese.
} 
Kumbe, M.: Music In Albania through the Medium of Paper Musical Manuscripts

Elbasan 87 is a codex written in 1808 , and classified as a Hirmologium - Anthology. Its musical notation belongs to the third period, in terms of the historical division of the notation, to the Eksegitical notation. This codex probably came to Albania from Trikala (Greece). In the f. $7 \mathrm{v}$, there is a record of the

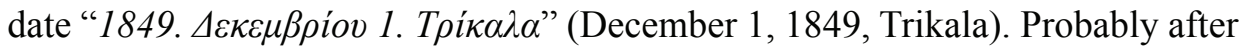
1849 , the manuscript was taken to the monastery of Saint Vladimir of Elbasan. The last folio contains the monastery's seal (Example 9). Something worthy to underline is that in the ff. $6 \mathrm{v}-8 \mathrm{r}$ exist a cryptografical record. In the ff. $6 \mathrm{v}, 7 \mathrm{r}$ and

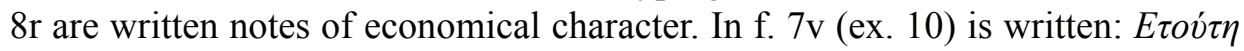

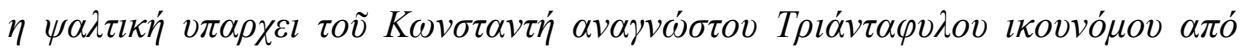
$\Pi \alpha \lambda \alpha \mu \dot{\alpha}^{7}$, (This psaltic book belongs to Konstanti anagnostou Triantafylou ikounomou from Palama).

\section{Examples 9 and 10}

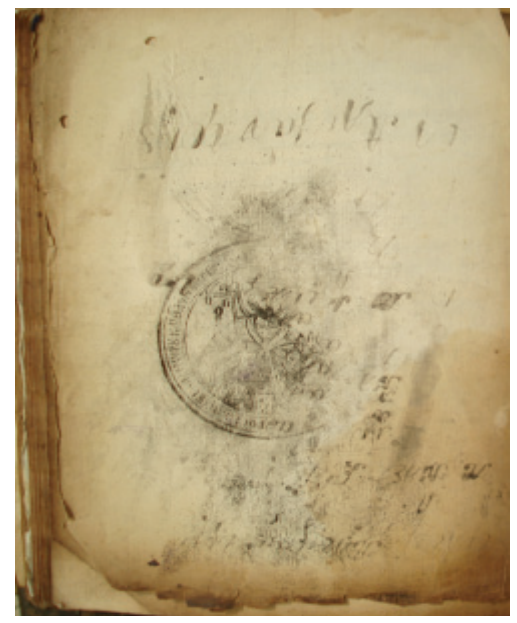

9) Elbasan 87, f. 168v

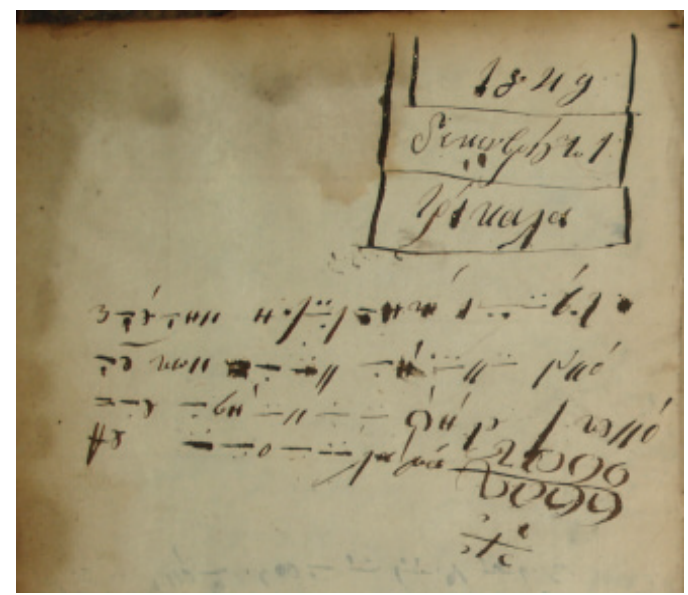

10) Elbasan 87, f. $7 \mathrm{v}$

Berat 90 and Tiranë 95 are two, small-sized manuscripts. They are respectively the Anastasimatario of Petro Peloponisio, from the $18^{\text {th }}-19^{\text {th }}$ century (exegetical musical notation) and a Mixed codex from the $19^{\text {th }}$ century $(\mathrm{New}$ Method).

Part of the collection bearing the number 488 is also the codex 101. This codex is a simple notebook of the $20^{\text {th }}$ century, which contains the musical Minologion (Example 11).

\footnotetext{
${ }^{7}$ The cryptographical notes were read by the Dr. Agamemnon Tsilikas
} 


\section{Example 11}

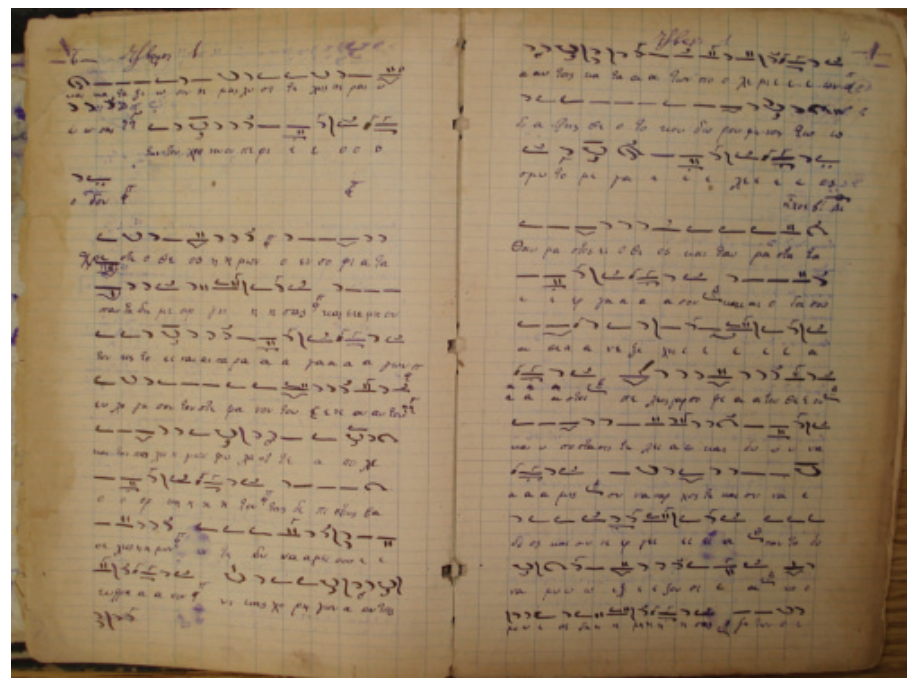

11) Codex 101, pp. 6-7

Byzantine notation was also encountered on the second folio of the codex Berat 9. This folio does not belong to the codex but was put there as a protective leaf in a later binding. This folio contains a fragment from the Mine of the month of August (Example 12)

During our research on the musical manuscripts, we found articles confirming our initial assumption, that there are more musical manuscripts that have been found to exist in Albania today, than we knew in the past. The first three testimonies came from the publications of Anthimes Alesksoudi. The initial one

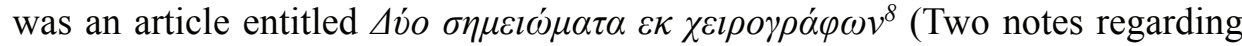
manuscripts), published in 1892, which tells us that among the manuscripts that Skouripeki saved, there was also an Ochtoecho. The second one was an article

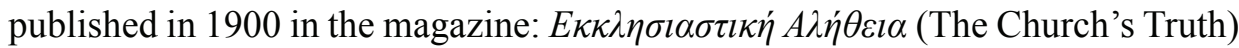

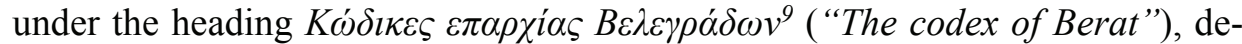
scribing another musical manuscript which Aleksoudi called an Ochtoecho. The

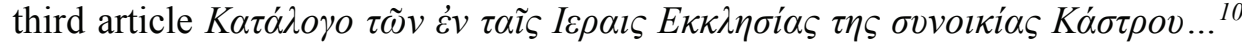
testifies to the existence of a manuscript from the year 1267, classified by Aleksoudi as Triodio - Pantikostario. He writes in his text that "this manuscript is

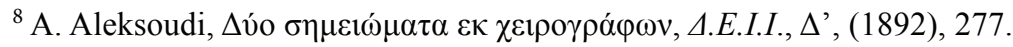

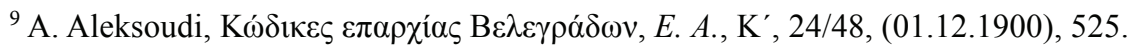

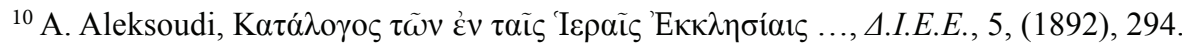




\section{Example 12}

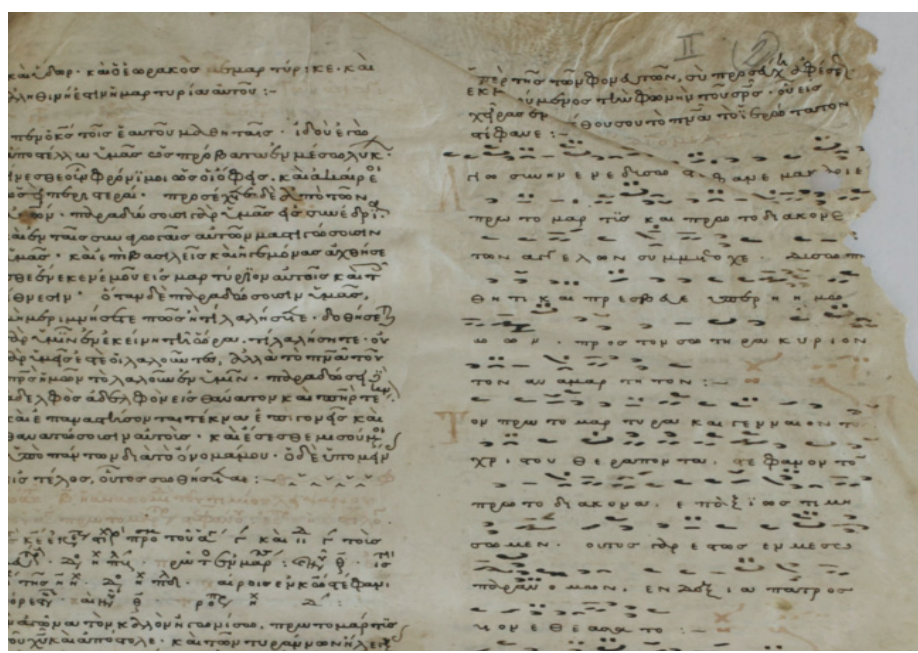

12) Berat 9 , f. $2 r$

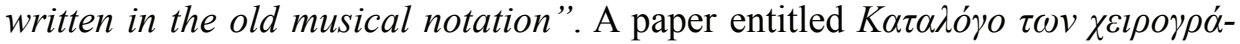

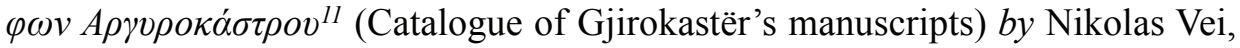
refers to a musical manuscript - Anthology - from the $18^{\text {th }}$ century.

Comparing the above evidence with the manuscripts that are kept in the Central State Archive, we observed that:

1. The manuscripts preserved in Albania today are not mentioned in articles published until 1960 and

2. The manuscripts described in these articles are not recorded today in the Central State Archive. We do not know anything about their existence. They may have been lost or taken outside of Albania, or still exist even today in unknown, private collections.

Albanian "papers", meaning articles or books published until 1990, never mentioned the musical manuscripts of Albania because that musical tradition of Albania and its story, were not studied or documented in any noteworthy measure during the communist period in the second half of the $20^{\text {th }}$ century. Unfortunately, because the regime in communist Albania in that period never considered those writings and the manuscripts to be an indisputable value of the country's heritage, they were almost always treated in keeping with this policy. Often the

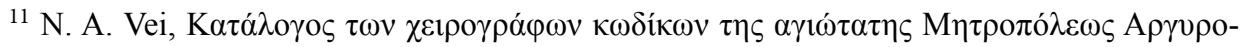

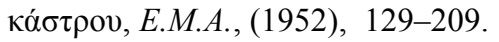


"papers", whether they were historical documents, literary writings or musical compositions, represented a high risk for the political regime and as such, were classified as "prohibited papers" (and most of them remained so until 1990). The consequences of the policies against the "papers" (historical documents, written works or compositions) were:

1. The barbaric behaviour toward the different monasteries or private libraries, the majority of which were looted by the state or other persons, and afterwards destroyed or burned. Also, many authors and composers were considered a "threat" and, as such, were arrested, persecuted, or executed; others left Albania after being condemned as fascist collaborators.

2. Preventing scholars from freely studying the resources and bibliography regarding Albanian music. Therefore, as a result, the book entitled The History of Albanian Music, ${ }^{12}$ published by the Institute of Arts (today the University of Arts), which is used as a textbook, is actually a distorted version of the history of Albanian music. It's history is what a political system wants it to be.

Under such conditions, these scores or musical manuscripts were destined to be forbidden, hidden and forgotten.

In conclusion, we could certainly say that the musical tradition of Albania - regardless of whether it is religious or profane - is still poorly researched, and even nowadays requires much more study. The musical manuscripts of Byzantine music were never mentioned before. The few people who knew or spoke out about their existence were jailed or were afraid to mention the codices, or anything else regarding religion. Despite their small number, the codices' existence is important for the country because they not only represent the very first evidence of musical notation in Albania but they also confirm the existence of the tradition of psaltic art in Albania. As was shown in Anthimos Aleksoudi's articles, this tradition was, for many centuries, an important part of the musical tradition of the Albanian people and, therefore, cherished for centuries.

\footnotetext{
${ }^{12}$ Historia e muzikës shqiptare, (Tiranë : Shtëpia Botuese e Librit Shkollor, 1984)
} 